\title{
Continuing Education a Necessity in the Professional Development of Teachers (Case Study Geography Teacher Profile - in Fier City, Albania)
}

\author{
PhD. Jostina Dhimitri \\ Department of Geography, Faculty of History and Philology, \\ University of Tirana \\ jostinak@yahoo.com \\ Associate Professor Valbona Duri \\ Department of Geography, Faculty of Education and Social Sciences \\ University "Eqrem Cabej" Gjirokastra \\ bongjeo@yahoo.com

\section{Associate Professor Merita Dollma} \\ Department of Geography, Faculty of History and Philology, \\ University of Tirana \\ meritadollma@yahoo.com
}

\section{Doi:10.5901/jesr.2014.v4n1p365}

\section{Abstract}

During their professional career, teachers need to be fulfilled professionally and consistently. Training and professional perfection of teachers affect directly on the quality of the educational process, largely on the success and effective development of students. In our educational system there are created training possibilities to help qualification and professional development of the teachers. Gained knowledge in the years of the university education require to be rich in the continuing education. The latest scientific contents in focus of the subject, the technological and pedagogical development, should be the focus of continuing education for teachers and their perfection of the profession. Continuing education of teachers is one of the essential characteristic of their own profession. Nowadays there are required teachers more and more professionally qualified, for this reason it has become necessary their professional perfection, so the education of teachers must be lifelong. Paper is focused on the aspects of teacher professional development throughout their teaching career by sampling geography teachers in Fier City, Albania. The addressed questionnaire assesses situation in this profile of teachers, creates opportunities for suggestions towards possible improvements.

Keywords: Continuing education, geography teacher, learning process, professional development.

\section{Introduction}

Teacher devotes all intellectual potential, his work in school and more successful achievements of the goals and tasks arising from his profession. In the perspective of lifelong learning, the teaching profession should be seen as a continuum which includes base teacher education, fostering professional and continuing professional development.

Recognition and assessment of professional development of teachers of geography profile is made object of the case study in schools of Fier city, through collected and analyzed data. Teachers perform various trainings to grow professionally. Through them, they realize their continuing education and status of the worker 5, 10, or 20 years in their professional careers as teachers, according to our education system. For this qualification, training teachers are certified by IZHA and MAS. Teachers are evaluated on the basis of teacher portfolio assessment, certificates and final test. Professional development are part of these certificates with credits and not only.

Continuing education is seen as a prerequisite for qualification and as a individual professional perfection of teachers. Xhemal Beluli states: "The purpose of modern education in Europe is the development of the continuing system of the professional perfection of the teachers that will reflect the new quality of learning and teaching; will enable the students the optimal development and that will be compatible with standards of most European countries". (Xhemali, 
Chap.1, ๆ 2). While in a publication LaNice Hill, a computer teacher, Oakdale Christian Academy, we see the importance Hill attaches to lifelong education, focusing on teacher training, which exams different methods and especially workshops. Hill estimates that: "Good teachers become great teachers by going beyond the call of duty and beyond the textbook. To do this, he or she must continue their education. There are conferences, workshops, and continuing education that could give the teacher that extra help in technology for their students" (Hill, ๆ 2). Linda Darling-Hammond also assesses another way of teacher learning. She in her article writes that: "Teachers learn best by studying, doing, and reflecting; by collaborating with other teachers; by looking closely at students and their work; and by sharing what they see. (Darling-Hammond, 1998, chap.2, I 1). Sheri Cyprus, suggests another way in terms of professional development for teachers and businesses and it could be on a particular day where seminars and workshops are held on various issues (Cyprus, 2013).

While opinions, information, models on teachers' professional development are spacious, offered by different actors that operate in education field; a special focus occupies the integration of formal educational institutions for the training of teachers, in order to realize of a better teaching-learning process. For this DAR (Regional Educational Directory) and ZA (Educational Office) by training sectors create opportunities which make possible the training of teachers in various themes throughout the year. Also the schools in their annual plans target the continuous training of teachers.

The whole information on continuing education and the professional development of teachers, calling into focus the geography teacher's profile in the Fier became part of the study and its results are introduces in this paper.

\section{Used Methodology and Sampling}

The descriptive survey design was focus in this paper. Questionnaire and interview were applied during the study. The number of teacher involved as respondent were 25 geography teachers that works in higher education. The questionnaires have been distributed and gathered during March 2013. This survey is designed to recognize the situation, evaluation, opinions on professional development for geography teachers in Fier City. Statistical methods come in assistance of further analysis. SPSS 20 software was used for processing.

There is used a questionnaire with 15 questions, where first three questions included demographic and educational data. The others questions include the focus of the study. The kinds of questions are different: opened, structured questions etc.

\section{Findings}

The study included 25 teachers, $72 \%$ of them were females and 28 males. According to age group $16 \%$ of teachers belonged to the age group 25-30 years old, $48 \%$ of teachers belonged to the age group $31-40$ years old, $32 \%$ belonged to the age group 41-50 years old and $4 \%$ belonged to the age group over 51 years old. It is noted the domination of teachers which might be qualified for at least in the testing for over 10 years working in teaching-learning process. All the teachers had graduated as the profile geography teacher.

In the presented paper, the propose is to survey and describe the situation on continuing education for professional perfection of teacher in geography profile.

The asked question (1) that: "At the end of university studies, it is achieved a complete professional perfection?", they are answered as: $28.0 \%$ of teachers think that the end of university studies it is achieved a complete professional perfection and $72.0 \%$ think that the end of university studies it is not achieved a complete professional perfection. The result present that most of the teachers evaluate the importance of professional perfection and it is part of every work day.

Question (2) "Do you feel the need for professional perfection?" they are responded: $96 \%$ of teachers with "Yes" and $4 \%$ of them with "No". In accordance with the first question, the next answer derivates this result, where teacher needed to be trained for further professional perfection.

Question (3)"What is the most favorite professional development form?". $36.0 \%$ of the teacher thinks that the preferred forms for professional perfection are training by DAR / ZA, $44 \%$ of them through self-training, $20 \%$ of them through open lessons hours. (Tab.1) 
Tab. 1. The most favorite professional development form?

\begin{tabular}{|l|c|c|c|}
\hline & Percent & Valid Percent & Cumulative Percent \\
\hline training by DAR/ZA & 36.0 & 36.0 & 36.0 \\
self-training & 44.0 & 44.0 & 80.0 \\
open lessons hours & 20.0 & 20.0 & 100.0 \\
Total & 100.0 & 100.0 & \\
\hline
\end{tabular}

This question showed that teacher preferred mostly to be trained by DAR/ZA and to be self-trained. So they need to be suggested by different way of using training by self-training form.

Question (4) "What is the most preferred place for implementation of training for a better professional perfection" teachers responded in this way: $44.0 \%$ of them thought that the most preferred place is inside the school and $56.0 \%$ of the teachers thought that the most preferred place is outside the school, somewhere organized by DAR / ZA.

Question (5) "Do you participate in any professional training this year?", 40\% of the teacher responded with "yes" and 60\% were not involved in professional training during 2012-2013 year. This question presented a lower percentage of teachers who was training last year that showed that the applying interest for professional perfection was not at that level which it was pretended. Question (6) "How they are realized?" 15 teachers have refused to answer, while $28 \%$ of teachers empathize that training are in good level and $12 \%$ of them thought that they are in very good level.

Question (7) that "Which of the category of geography teachers need for a greater professional perfection?", 35\% of teachers think for beginning teachers, $4 \%$ for experienced teachers and $61 \%$ of for all teachers. The answer showed that professional perfection is part of teacher job and it is long life learnig.

Question (8) "What is the effect of professional perfection?" we grouped responses in Tab. 2:

Tab. 2. The effect of professional perfection to teacher

\begin{tabular}{|l|c|c|c|}
\hline & Percent & Valid Percent & Cumulative Percent \\
\hline important & 8.0 & 8.0 & 8.0 \\
Very important & 60.0 & 60.0 & 68.0 \\
Less important & 32.0 & 32.0 & 100.0 \\
Total & 100.0 & 100.0 & \\
\hline
\end{tabular}

Teachers estimated that effect of professional perfection is very important to teacher profession.

Question (9) "How much (in \%) do you feel professionally fulfilled?" Teachers responded as shown in Tab 3. However teachers believed that they are fulfilled enough, to develop their profession.

Tab. 3. How much (in \%) do you feel professionally fulfilled?

\begin{tabular}{|c|c|c|c|c|}
\hline & Frequency & Percent & Valid Percent & Cumulative Percent \\
\hline $0-25 \%$ & 1 & 4.0 & 4.0 & 4.0 \\
$26-50 \%$ & 1 & 4.0 & 4.0 & 8.0 \\
$51-75 \%$ & 9 & 36.0 & 36.0 & 44.0 \\
Over76\% & 14 & 56.0 & 56.0 & 100.0 \\
Total & 25 & 100.0 & 100.0 & \\
\hline
\end{tabular}

Question (10) "What terms would you like to be more trained?" Teachers responded with: 4\% in pedagogical terms, 44\% in the latest scientific information, $40 \%$ in various educational information, and $12 \%$ for the first and the second point took together. The answers emphasized the thematic orientation of training need, for geography teacher, mostly in the latest scientific information and in various educational information.

The last question (11) "Which aspects do you think the continuing education serves most?" The teacher responded as shown in Tab.4. 
Tab.4. Which aspects do you think the continuing education serves most?

\begin{tabular}{|l|c|c|c|c|}
\hline & Frequency & Percent & Valid Percent & Cumulative Percent \\
\hline The use of IT in teaching & 2 & 8.0 & 8.0 & 8.0 \\
Communication in teaching & 10 & 40.0 & 40.0 & 48.0 \\
Planning in teaching & 3 & 12.0 & 12.0 & 60.0 \\
The work with students in need & 3 & 12.0 & 12.0 & 72.0 \\
Pedagogical work in Class & 7 & 28.0 & 28.0 & 100.0 \\
Total & 25 & 100.0 & 100.0 & \\
\hline
\end{tabular}

The answers about these categories showed that training for communication in teaching and pedagogical work in class are the important for most of the teachers.

For the further analysis we have applied Cross tabulation between different questions.

First Cross tabulation between question 3 and question 10 (Tab. 5) presented that most of the teachers preferred self training and training organized by DAR/ZA, especially for the latest scientific information (subject information and their technological skills).

Tab. 5. Q3 * Q10 Crosstabulation 1

\begin{tabular}{|c|c|c|c|c|c|c|}
\hline & \multicolumn{4}{|c|}{ Q3 } & \multirow{2}{*}{ Total } \\
\hline & & Pedagogical terms (a) & the latest scientific information (b) & others & $a+b$ & \\
\hline \multirow{2}{*}{ training by DAR/ZA } & Count & 0 & 4 & 3 & 2 & 9 \\
\hline & $\%$ of Total & $0.0 \%$ & $16.0 \%$ & $12.0 \%$ & $8.0 \%$ & $36.0 \%$ \\
\hline \multirow{2}{*}{ Q3self-training } & Count & 1 & 5 & 5 & 0 & 11 \\
\hline & $\%$ of Total & $4.0 \%$ & $20.0 \%$ & $20.0 \%$ & $0.0 \%$ & $44.0 \%$ \\
\hline \multirow{2}{*}{ open lessons hours } & Count & 0 & 2 & 2 & 1 & 5 \\
\hline & $\%$ of Total & $0.0 \%$ & $8.0 \%$ & $8.0 \%$ & $4.0 \%$ & $20.0 \%$ \\
\hline \multirow{2}{*}{ Total } & Count & 1 & 11 & 10 & 3 & 25 \\
\hline & $\%$ of Total & $4.0 \%$ & $44.0 \%$ & $40.0 \%$ & $12.0 \%$ & $100.0 \%$ \\
\hline
\end{tabular}

In another cross tabulation between the age group of the teacher and the question 3, (Tab. 6) we see that the teacher of age-group 31-40 years old and 41-50 years old, preferred mostly training from DAR/ZA and self training.

Tab. 6. The age group of the teacher and Q3 Crosstabulation 2

\begin{tabular}{|c|c|c|c|c|c|}
\hline & \multicolumn{3}{|c|}{ Q3 } & \multirow{2}{*}{ Total } \\
\hline & & training by DAR/ZA & self-training & open lessons hours & \\
\hline \multirow{4}{*}{ Age --group } & $25-30$ years old & 0 & 2 & 2 & 4 \\
\hline & $31-40$ years old & 4 & 6 & 2 & 12 \\
\hline & $41-50$ years old & 4 & 3 & 1 & 8 \\
\hline & $51-60$ years old & 1 & 0 & 0 & 1 \\
\hline
\end{tabular}

This last cross tabulation between age group and question 9, noted that by increase of the teacher age, they felt more fulfilled professionally.

Tab. 7. The age group of the teacher and Q9 Crosstabulation 3

\begin{tabular}{|c|c|c|c|c|c|c|}
\hline & \multicolumn{4}{|c|}{ Q9 } & \multirow{2}{*}{ Total } \\
\hline & & $0-25 \%$ & $26-50 \%$ & $51-75 \%$ & mbi $76 \%$ & \\
\hline Age --group & $25-30$ years old & 1 & 1 & 2 & 0 & 4 \\
\hline
\end{tabular}




\begin{tabular}{|c|c|c|c|c|c|}
\hline 31-40 years old & 0 & 0 & 4 & 8 & 12 \\
41-50 years old & 0 & 0 & 3 & 5 & 8 \\
51-60 years old & 0 & 0 & 0 & 1 & 1 \\
Total & 1 & 1 & 9 & 14 & 25 \\
\hline
\end{tabular}

\section{Conclusion}

Continuing education for professional education is an important part teaching. Technological developments, information for innovations in science, pedagogical improvements, are a need of teacher to the everyday work. Forms of obtaining this information are numerous. They are offered by government and private institutions that act in education field.

Study reflected situation and need for training of geography teachers in schools of Fier city (Q2). They emphasized those teachers professional perfection is part of lifelong education (Q1). They preferred to be trained by DAR / ZA and to be involved on self training. Study presented that most of them (60\%) had not taken part in a vocational training last year, despite the $60 \%$ state that their effects on professional perfection are very important. Most of them are interested in the newest scientific, technological and educational developments. They think that training will serve more communication during teaching and learning, teaching and educational work in schools. Cross tabulation showed that while most favorite trainings are conducted by DAR / ZA they should be for topic scientific news and education in general. Teachers compile 31-40 years old were focused mostly on self training. Also teacher of age group 31-40 years old and 41-50 years old, feel fulfilled professionally, over 50\%. This study can be a source for further studies on the continuing education in the teaching profession. It serves teachers, trainers and other actors operating in the field of education.

\section{References}

Beluli, Xh. Përsosja profesionale e arsimtarëve, Sh.F. "Naim Frashwri", Tetovo. Retrieved November 10, 2013, from http://www.naimfrasheri.org/index.php?option=com_content\&view=article\&id=18\%3Appa1\&catid=10\%3Aap\&ltemid=18\&lang=sq

Cyprus,Sh. 2013, What is a professional teacher day, Retrieved November 10, 2013, from http://www.wisegeek.com/what-is-aprofessional-development-day.htm

Darling-Hammond, L. Teacher Learning That Supports Student Learning, Educational Leadership, Retrieved November 14, 2013, from http://www.ascd.org/publications/educational-leadership/feb98/vol55/num05/Teacher-Learning-That-Supports-StudentLearning.aspx

Hill, L. The value of workshops and continuing education for teachers, published by, The evolution, Illuminating lifelong learning movement, Retrieved November 11, 2013, from http://www.evolllution.com/opinions/the-value-of-workshops-and-continuingeducation-for-teachers/

http://www.google.al/url?sa=t\&rct=j\&q=\&esrc=s\&frm=1\&source=web\&cd=16\&ved=0CE8QFjAFOAo\&url=http\%3A\%2F\%2Fwww.mindme ister.com\%2Fgeneric_files\%2Fget_file\%2F3609872\%3Ffiletype\%3Dattachment_file\&ei=2tGEUq21KYfn4gSIh4HABw\&usg=AFQ jCNEHB9RWNp8zPjIcjS7BSt_qGPYD4A consulted November 12, 2013.

Instituti i Kurrikulës dhe i Trajnimit, 2009, Mësuesit dhe cilësia e arsimit sfidë globale e shekullit XXI, Tiranë,

Instituti i Kurrikulës dhe i Trajnimit, 2009. C'ndryshime solli kualifikimi i mësuesve, Tiranë.

Instituti i Zhvillimit të Arsimit, 2010, Kualifikimi i mësuesve, Tiranë.

Salkind, N. 2000, Statistics for people who (think they) hate statistics, Saga Publications, Inc. 
